\title{
THE UNITED STATES DEPARTMENT OF AGRICULTURE
}

\author{
By A. C. True,
}

Director, Office of Experiment Stations, United States Department of Agriculture.

From a humble beginning in the Patent Office in 1839 , the work of the federal government relating to agriculture has steadily grown in extent and importance. As a separate department the semi-centennial of the department will occur this year (1912), and for nearly half that time its chief officer has had a seat in the President's cabinet. Its annual appropriations now aggregate about $\$ 20,000,000$. Its paid employees number about 13,000 , of whom about 2,500 are stationed at Washington. Its agents are found in every state, territory and outlying possession of the United States, and in many foreign countries. In the extent of its business and the variety of its operations it far surpasses any similar organization in the world.

For the past fifteen years, which constitute the period of its most rapid and complete development, it has had the unique experience of being under the general management of the same chief executive, Secretary James Wilson, of Iowa. As a pioneer in the development of our greatest agricultural region, a successful farmer, a politician and congressman of long experience and great popular favor, a student of agricultural science and teacher in an agricultural college, he came to the department with experience and qualifications which fitted him in a very unusual degree for the great task ahead of him.

As a member of the cabinet under three presidents, he has taken an active part in the general administrative work of the government and in the political activities which under our form of government are inseparable from such a position.

In the management of the department he has maintained a broad and non-partisan policy as regards both the lines and location of its work and the appointment and retention of its personnel. The interests of all parts of the country have been carefully and impartially considered in the development of the department's work. The permanent tenure of office for efficient employees has been jealously guarded, the great mass of appointments have been regularly made 
from the registers of the Civil Service Commission, and the relatively large number of technical and scientific experts and agents, who in accordance with special legislation and regulations have been appointed outside the classified civil service, have been chosen with reference to their qualifications for the work expected of them. As a whole, the general policy of the department will compare favorably with that of our best educational and scientific establishments maintained as public institutions. It is certainly very encouraging that the elevation of the department to the first rank of governmental establishments and its consequently close union with the presidential office have resulted in a progressive development of non-partisan policies and scientific ideals and practices in the conduct of its business.

The act of congress of 1862 which gave the department its separate existence laid the general foundation for its work in these words: "There is hereby established at the seat of government of the United States a department of agriculture, the general designs and duties of which shall be to acquire and diffuse among the people of the United States useful information on subjects connected with agriculture in the most general and comprehensive sense of that word and to procure, propagate and distribute among the people new and valuable seeds and plants." Information was to be gathered "by means of books and correspondence and by practical and scientific experiments, by the collection of statistics and by any other appropriate means."

Special legislation has since further defined and extended the functions of the department. Some duties outside the pale of agriculture however broadly defined have been committed to the department's charge. On the other hand, the definition of agriculture as applied to the work of educational and scientific institutions has been so widened in recent years that the operations of the department-extensive and far-reaching as they are-do not yet in all respects cover the field of work marked out for it in its charter.

In its "most general and comprehensive sense" as applied to institutions for its promotion agriculture now includes not only whatever relates to the production of plants and animals useful to man and their use as closely related with their production, but also much that has to do with the organization and life of rural communities. Under this definition the main divisions of agriculture 
are ( 1 ) plant production, including agronomy (field crops), horticulture and forestry; (2) animal production, including the breeding, feeding and management of animals, and veterinary medicine; (3) agrotechny, including the standardization of agricultural products as regards purity, efficiency, etc., and the manufacture of such products as are closely related with the farm (e.g., dairying, sugarmaking, etc.) ; (4) rural engineering, including roadmaking, irrigation, drainage, farm buildings and machinery, etc.; (5) rural economics and sociology.

The broadest work of the department has been on matters relating to plant production and has covered widely agronomy, horticulture and forestry. Under animal production the greatest work has been in veterinary medicine. The work on breeding, feeding and management of animals has been quite limited as compared with that done by the agricultural colleges and experiment stations, but is more definitely organized and in recent years has been considerably expanded. Under agrotechny a large amount of work has been done in the establishment of standards for foods and seeds, and the determination of adulterations of these materials. Considerable work has been done on matters relating to sugar-making, dairying, etc. In recent years the work of the department relating to roads, irrigation and drainage has been definitely organized and is rapidly expanding. Though the United States far surpasses the other nations in the manufacture and use of farm machinery, and though this involves large economic and social questions vitally affecting our rural communities, very little attention has been given to these subjects by the department, and congress has not been willing to extend its work in these lines. Aside from the regular collection of crop statistics and the publication in a limited way of information bearing on economic problems the department has thus far done very little in rural economics and sociology. In recent years, however, it has given some attention to studies of the distribution of agricultural products and the problems of farm management.

As perhaps a natural outgrowth of its functions relating to the industry which is most fundamental to human life and civilization, the department has taken on an increasing amount of work outside the field of agriculture. Such, for example, is a large part of the work of the Weather Bureau, the inspection of drugs, investigations 
on human nutrition, studies of household and disease-causing insects, biological investigations relating to human disease, etc. Part of this has been given to the department under a wise administrative policy which seeks to make the most effective use of existing governmental agencies and facilities instead of creating new ones.

At the outset the educational and scientific institutions organized in this country for the promotion of agriculture dealt very largely with the sciences related to agriculture rather than with agriculture itself. This tendency was manifested in the organization of the department, where divisions were created for studies in chemistry, botany, entomology, ornithology and mammology. About the time of Secretary Wilson's coming to the department a movement arose to enlarge and specialize the more strictly agricultural work of the land-grant colleges and to base the organization of the colleges of agriculture on the divisions of agriculture considered as both an art and a science. In the department the Bureau of Animal Industry had already been established. All the work in agronomy, horticulture and agricultural botany was brought together in the Bureau of Plant Industry. Bureaus of forestry and soils and an office of public roads were created. The Weather Bureau was brought into the department. There are now also bureaus of chemistry, entomology, biological survey, and statistics. In I 888 the office of experiment stations was created to represent the department in its relations with the state experiment stations. This office has since been charged with investigations in irrigation, drainage, human nutrition and agricultural education. The great expansion of the department's work in lines directly relating to the practice of agriculture has given it a much wider and stronger influence among our rural people. At the same time the scientific work in lines related to agriculture has been greatly broadened and strengthened.

To understand the broad influence which the department now has among all classes of our people and the results which it has been able to accomplish in the promotion of agriculture, it is necessary to consider at least the main divisions of its work. Broadly classified the functions of the department are (I) administrative, (2) advisory, (3) investigational, (4) informational, and (5) educational.

Under administrative duties are those relating to the enforcement of the meat inspection, food and drug and insecticide and 
fungicide laws with regard to both domestic and imported products; the control of quarantine for imported cattle and of interstate quarantine rendered necessary by sheep and cattle diseases and the inspection of cattle carrying vessels; the management of the national forest reserves; the regulation of interstate commerce of game animals and the control of the importation of noxious and other animals; the congressional seed distribution; the supervision of the federal funds granted to the state agricultural experiment stations and the direct management of the stations in Alaska, Hawaii, Porto Rico and Guam.

The meat inspection includes the ante-mortem and post-mortem inspection of cattle, sheep, swine and goats slaughtered at establishments engaged in interstate or foreign commerce; the supervision of such establishments and of the various processes of preparing, curing, canning, packing, etc., so as to insure sanitary conditions, equipment and methods; the marking and certification of meats and meat products; and the regulation of interstate transportation and exportation of such products. This inspection is carried on at 936 establishments in about 255 cities and towns. In I9I I there were inspected at slaughter $52,976,948$ animals and I,127,055 carcasses or parts of carcasses were condemned. The inspected animals furnished I0,000,000,000 pounds of meat. On reinspection $210,073,577$ pounds of meat were condemned which had become unfit for food since the time of slaughter.

Live stock is also inspected at points of shipping, in transit and at market centers, cars are disinfected and quarantining and other measures are taken to eradicate or prevent the spread of contagious diseases of animals through interstate commerce. The quarantine against Texas fever of cattle in the southern states is being gradually restricted through the eradication of the ticks causing this disease. About 140,000 square miles, or one-fifth of the original infected area, have been cleared of ticks and released from quarantine during the past five years. In a similar way the parasitic diseases known as scabies of sheep and cattle, against which quarantine is necessary, are being eradicated in the western states. Over $1,000,000$ doses of black leg vaccine were sent out and about 500,000 doses of tuberculin and mallein were furnished to local officials for the diagnosis of tuberculosis and glanders.

Inspections of hundreds of thousands of American and Cana- 
dian animals for export are annually made, as well as of all animals imported from foreign countries.

The manufacture of $44,115,05^{8}$ pounds of renovated butter was supervised at thirty-eight factories in thirteen states. The certifying of the pure breeding of all animals imported for breeding purposes has been undertaken under a provision of the tariff act.

The extensive operations of the department relating to animal industry have great economic importance. Their influence is broadly national and international. They affect profoundly the economic conditions relating to the growing of domestic animals and the commerce in them and their products. The quality and prices of animals and meat on the farm and in the market are in a measure determined by government regulation.

The same things may be said regarding the department's enforcement of the food and drugs act. Through its laboratory in the Bureau of Chemistry at Washington and twenty-one branch laboratories scattered throughout the country, the department is exercising a rigid inspection of a great variety of foods and drugs which enter into interstate and foreign commerce. Nearly one thousand two hundred cases were reported the past year for criminal prosecution or seizure of adulterated and misbranded goods. Besides its economic results as affecting the marketing, storage and prices of such materials, this work, as well as that of meat inspection, has a broad influence on the health of people in both city and country.

The management of the national forests involves the administrative control of $192,000,000$ acres or 300,000 square miles of territory in the western states and Alaska,-a domain equivalent to the combined areas of Massachusetts, Rhode Island, Connecticut, New York, Pennsylvania, Ohio, Indiana, Illinois and Iowa. About $500,000,000$ board feet of lumber were cut in the forests last year and the contracts for sale entered into during the year disposed of over $\$ 2,000,000$ worth of timber. Grazing permits, issued for $8,898,500$ animals, yielded $\$ 935,490$. Extensive operations in road building, fire protection and reforesting are going on. A beginning has been made of the examination and purchase of forest lands in the White Mountains and the Southern Appalachians under the Weeks act, approved March I, I9I I. The policy of the department, as stated by Secretary Wilson, is to maintain, protect and improve the vast tract in the national forests for the public benefit and for 
use as public utilities. "Their primary uses are to produce continuous supplies of timber and to regulate the flow of water. Subordinate to these uses, yet of large importance, are their use for grazing, for recreation and for many kinds of occupancy." When the national forests are fully developed and utilized it is evident that they will be a large factor in the agriculture of the country and in its industrial development.

Through its Biological Survey the department is doing much to prevent the rapid destruction of game animals and birds, "to establish public game preserves and bird reservations, and to prevent the importation of animals likely to become pests. In a similar way the Bureau of Entomology is aiding the states in maintaining a quarantine against the further spread of the gipsy and browntail moth, which have already proved so destructive in eastern New England, and is co-operating with the forest service in the war on forest insects.

The supervision of the federal funds granted to the state experiment stations has been committed to the office of experiment stations. These funds now aggregate $\$ 1,440,000$ annually, and are given to forty-eight states and territories. They are supplemented by more than an equal amount derived from the states and local sources. This office also has administrative control of the stations in Alaska, Hawaii, Porto Rico and Guam, for which congress annually appropriates over $\$ 100,000$. The operations of the sixtyfive stations in the United States cover every phase of the country's manifold agricultural industries.

The purchase, testing and distribution of vegetable and flower seeds on the orders of congressmen, which originally was the largest function of the department, is now a minor administrative matter. Between six and seven hundred tons of seeds, in about $60,000,000$ packets, were distributed the past season.

In its advisory capacity the department conducts a vast and varied correspondence. Besides this there are some large operations which have in them an important advisory factor. Such, for example, are the daily weather forecasts which are generally available to the farmers, as well as other classes of people, throughout the country. In this category may also be included the monthly crop reports, the national soil survey and the co-operative farm demonstration work in the southern states. 
Many agents of the department are now giving much time to personally advising the farmers in the districts where they are located. Notable examples of this are the services of the department's road, irrigation and drainage engineers, who are now widely sought for as consulting experts concerning large, difficult or special problems which are not easily handled by the local authorities. In a similar way the office of experiment stations has had a broad influence on the development of the agricultural colleges, schools and experiment stations. The advisory work of the department shows an interesting development of a relatively new governmental function. It is evident that the people are looking more and more to the federal government as a broad, expert and impartial agency able and willing to give them advice on many important matters connected with their daily lives. With relatively little administrative control the government is thus able to exert a very great influence in the affairs of the people.

The technical, scientific and practical investigations of the department constitute a large share of its business and cover a very wide range. All the bureaus are engaged in this work and a mere list of the projects would far outrun the limits of this article. They include laboratory investigations in a number of sciences, field experiments in many states and territories, studies of natural conditions and agricultural possibilities on a broad scale, the exploration of many foreign countries for plants, beneficial insects, etc., the devising of means to defend the farmer against fraud or to protect him against the ravages of insects and diseases, economic studies relating to farm management, cost of crop production, etc., etc. Taken together they constitute the largest amount of definite and systematic investigation conducted under a single organization that can be found anywhere in the world. United with the similar work of the state experiment stations, they are accumulating a body of knowledge relating to agriculture which is already by far the largest contribution to the science of agriculture. In this way a broad, sure and permanent foundation for the future agricultural prosperity of the United States is being laid.

As a public agency for the dissemination of information on agricultural subjects the work of the department has reached vast proportions. During the year ended June 30 , I9I I, the department issued I,953 publications, aggregating 27,594,877 copies. Many of 
these are technical reports of scientific investigations published in small editions, but others are popular in character and are widely distributed. The series of brief farmers' bulletins is largely distributed by congressmen and thus is sent into all the rural districts. Over 9,000,000 copies of farmers' bulletins are distributed annually. The "Yearbook," a bound volume of about seven hundred pages, has an edition of 500,000 copies. Any person in the United States on application can be enrolled on the mailing list to receive regularly the monthly list of department publications, and thus can know about everything which the department publishes. It is the policy to send free of charge any publication the department has in stock and to reprint as long as there is any considerable demand. After that applicants are referred to the superintendent of documents at the government printing office, from whom any document can be procured at a nominal price. The department publishes summaries of its own publications, those of the state experiment stations, and all other literature of agricultural science published throughout the world in the journal entitled "Experiment Station Record." This is sent to numerous institutions and scientists and may be found in hundreds of libraries in this country and abroad. The department library contains about II6,000 books and pamphlets, chiefly on agricultural subjects, and currently receives nearly two thousand periodicals. This library is freely open to readers and books are loaned to agricultural colleges and experiment stations and other scientific institutions. The officers of the department deliver numerous lectures before farmers' institutes, agricultural, scientific and other organizations in all parts of the country. A vast amount of information is also distributed by correspondence and through the agricultural and general press.

The department, however, is not content with distributing agricultural information, but goes further than this and directly promotes agricultural education throughout the United States. It does this because it believes that in the long run the permanent prosperity of our agriculture and the highest welfare of our rural people, as well as of the whole nation, will depend on the trained ability of our farmers and their families to make the best use of our lands and to maintain well organized rural communities. The rural people, therefore, need a sound and thorough education which will adapt them to their environment and make them efficient workers 
in the service of mankind. There should be a broad education for citizenship and life in the modern world, including a fair share of training in the science and art of agriculture and home economics. The department is, therefore, giving much attention to agricultural education.

The office of experiment stations is especially charged with the educational business of the department, but the other bureaus are also doing much to promote this cause. The work is largely done in co-operation with the United States Bureat of Education, the Association of American Agricultural Colleges and Experiment Stations, the state departments of education and agriculture. The general purpose is to collect and distribute information regarding the progress of agricultural education throughout the world, to study the agricultural and pedagogical requirements of a modern educational system for rural people, to aid the several states in broadening and redirecting their school system to meet these requirements, to supply the schools with the knowledge accumulated by the department and the experiment stations which can be utilized to make their courses in agriculture and home economics more satisfactory and effective, and to carry on propaganda, as far as may be necessary, among our rural people, in the interests of improved methods of education.

This work is done partly through publications, but more largely by public addresses and conferences with educational and agricultural leaders in the several states. It covers broadly the work of the agricultural colleges, secondary and elementary schools, farmers' institutes and other forms of extension work. The Bureau of Plant Industry is contributing largely to this latter phase of the educational movement by distributing seeds for school gardens and by forming boys' and girls' clubs for the growing of corn, canning of tomatoes, etc., in co-operation with the public schools in the South. 